\title{
MODEL TASK-BASED LEARNING UNTUK MEMBANGUN PEMBELAJARAN MANDIRI PADA TUTORIAL ONLINE
}

\author{
Athiyah Salwa \\ Sekolah Tinggi Elektronika dan Komputer (STEKOM-PAT) \\ e-mail: athiyahsalwa1@gmail.com
}

\begin{abstract}
Distance learning organized by Universitas Terbuka provides many benefits and opportunities for students in remote areas to get higher education services. For the time being, this learning program is facilitated by e-learning assistance program using technology and information media. This learning process emphasizes unlimited materials for students outside the main source, Buku Materi Pokok, that can be accessed whenever and wherever. The main focus of this tutorial online is to give a chance for students to learn in their free time, give them learning assistance, and measure how they understand the materials given. This emphasizes the learning process independently and autonomously. This article tries to give a new sight in this Tutorial Online about a technique or a model that can be applied. This model encompasses practices, assignments, and tasks can be done independently by students. This learning model will improve and build students' autonomous learning by providing them with authentic yet simple tasks, practical and independent assignments.
\end{abstract}

Keywords: Autonomous Learning, Online Learning, Task-Based Approach

\section{A. PENDAHULUAN}

Berkembang pesatnya teknologi informasi dan penggunaan Internet yang kian massif di era digital saat ini secara langsung membawa dampak yang baik dalam dunia pendidikan. Proses belajar mengajar saat ini tidak terbatas hanya dalam ruang kelas dan waktu pembelajaran yang ketat seperti dua dekade yang lalu. Proses belajar yang dahulu "hanya" berupa transfer ilmu dari guru/dosen ke siswa sekarang telah beralih lebih maju ke media elektronik baik itu komputer, gawai, dan telepon selular yang dapat diakses oleh mahasiswa kapanpun mereka inginkan. Bergesernya pola belajar ini membuat akademisi baik di lingkungan pendidikan dasar maupun pendidikan tinggi berlomba-lomba untuk menyajikan materi belajar dengan memanfaatkan media teknologi informasi yang dapat diakses dengan mudah dengan fasilitas internet yang makin baik di Indonesia saat ini.

Universitas Terbuka sebagai perguruan tinggi yang melaksanakan pembelajaran jarak jauh juga telah melakukan model pembalajaran online ini untuk membantu mahasiswa belajar dengan baik. Banyaknya mahasiswa UT tersebar di seluruh penjuru negeri bahkan dunia, menuntut UT untuk menyelenggarakan bantuan belajar dengan media internet. Pelaksanaan layanan belajar online sesuai dengan Rencana Strategis UT 2010-2021 yang menyebutkan bahwa di pada tahun 2021 UT menyediakan berbagai bentuk bantuan belajar berbasis TIK yang memiliki akurasi tinggi dan telah menerapkan sistem tata kelola pembelajaran yang berbasis TIK (Universitas Terbuka, 2011). Selain itu, fungsi dari pembelajaran online adalah untuk meningkatkan mutu UT sebagai perguruan tinggi negeri yang mampu mendapatkan pengakuan dan apresiasi dari masyarakat luas (Sugilar, 2014) 
sehingga mahasiswa lulusan UT memiliki kompetensi yang sebanding dengan mahasiswa perguruan tinggi negeri lainnya.

Bantuan belajar online ini merupakan salah satu bantuan belajar yang ada di UT. Jenis layanan bantuan belajar lainnya adalah tutorial tatap muka, tutorial online, tutorial televisi, tutorial radio, penyediaan Latihan Mandiri, web-based supplement, dan berbagai portal pembelajaran (https://www.ut.ac.id/2015/9-uncategorised-id/591-layanan-tutorial-online-di-ut). Mahasiswa diharapkan dapat memanfaatkan layanan bantuan belajar ini untuk meningkatkan pemahaman terhadap materi dan mampu mencapai nilai yang optimal pada Ujian Akhir. Tutorial Online ini diharapkan dapat memfasilitasi mahasiswa sama halnya dengan Tutorial Tatap Muka (yang juga merupakan layanan bantuan belajar UT). Sama halnya dengan Tutorial Tatap Muka, mahasiswa juga mendapatkan materi tambahan diluar Buku Ajar Pokok dan dapat berinteraksi dengan tutor. Selain itu tutor juga melaksanakan perannya dalam memberikan penilaian, arahan, memberikan komentar, dan umpan balik terhadap jawaban dan hasil tugas mahasiswa.

Materi tambahan yang disajikan oleh tutor biasanya disajikan berupa paparan atau rangkuman yang menunujang teori dalam BMP sesuai dengan Rancangan Aktivitas Tutorial (RAT) yang sudah disusun oleh tim UT. Materi ini dibuat oleh satu orang master tutor yang kemudian disajikan secara seragam di semua kelas tutorial online. Hal ini untuk menghindari adanya perbedaan materi yang diberikan oleh setiap tutor mengingat banyaknya kelas yang ada dalam tutorial online. Selain itu materi ini juga dilengkapi dengan video dan sumber belajar lain yang tersebar di internet serta di bagian akhir terdapat latihan mandiri atau soal untuk menilai seberapa jauh pemahaman mahasiswa terhadap materi yang disajikan. Meskipun mahasiswa dapat berinteraksi dengan tutor setiap saat, namun kendala yang sering terjadi adalah tutor tidak bisa menjamin apakah pekerjaan yang diberikan di setiap minggu baik berupa tugas ataupun latihan mandiri benar-benar dikerjakan secara mandiri oleh peserta tuton atau tidak. Adakalanya mahasiswa yang memiliki performa baik di tuton, pada saat ujian akhir mereka mendapatkan nilai yang rendah. Untuk itu, nilai yang didapat dari aktifitas belajar di tutorial online tidak berkontribusi banyak terhadap nilai akhir mahasiswa. Kontribusi nilai tuton terhadap nilai akhir sebesar maksimal $30 \%$ (https://www.ut.ac.id/tutorial-online). Hal ini untuk menghindari adanya kecurangan mahasiswa yang berlindung dengan mengandalkan nilai pada Tutorial Online saja.

Mahasiwa UT yang tersebar di seluruh penjuru dunia memiliki latar belakang yang sangat heterogen antara satu daerah/negara dengan daerah/negara yang lainnya. Mahasiswa UT tersebar di 32 negara yang jumlahnya 4000 orang dan kebanyakan dari mereka adalah Tenaga Kerja Indonesia (www.ut.ac.id). Tidak jauh beda dengan mahasiswa di luar negeri, mahasiswa yang berada di dalam negeri-pun kebanyakan sudah bekerja. Program belajar yang diselenggarakan oleh UT sangat membantu mereka untuk meneruskan pendidikan mereka terlebih adanya bantuan belajar seperti Tutorial Online yang memberikan kesempatan kepada mereka untuk berinteraksi dengan tutor.

Kendala yang dihadapi dalam bantuan belajar ini salah satunya bersumber dari keheterogen-an peserta. Adakalanya karena materi yang kurang menarik dan kurang kaya akan penjelasan, justru menambah kebingungan mahasiswa dalam memahami materi. Ini berdampak terhadap jawaban yang diberikan atas soal dan tugas yang diberikan. Mahasiswa masih menemui kendala dalam mengerjakan soal, karena minimnya akses dengan sumber belajar yang lain ataupun kurangnya umpan balik dari tutor. Sebaliknya, ada juga mahasiswa yang dapat memahami dengan baik dan mendapatkan hasil/nilai yang baik dalam tutorial online, namun pada saat Ujian Akhir ia 
tidak dapat mendapatkan nilai yang sama. Terdapat kekhawatiran bahwa hasil belajar yang didapat tidak otentik/murni berasal dari buah pikiran mahasiswa tersebut.

Berangkat dari kondisi inilah maka perlu adanya instrument dan bahan penilaian yang bersifat real sesuai dengan materi dan mata kuliah yang diajarkan. Mahasiswa akan mampu menangkap dengan baik materi yang disajikan dalam kegiatan tutorial online (yang mengacu pada Rancangan Aktifitas Tutorial dan Buku Materi Pokok) jika tugas yang diberikan disajikan secara konseptual dan riil. Yang dimaksud real disini adalah tugas disajikan secara nyata sesuai dengan apa yang akan mereka hadapi kelak di luar "kelas". Tugas yang disajikan oleh guru atau dosen di dalam kelas akan menjadi tugas pedagogi sedangkan tugas yang sesungguhnya adalah tugas secara nyata dalam bentuk penerapan teori kedalam dunia kerja praktek di lapangan. Nunan menyebutkan bahwa tugas pedagodik adalah salah satu pekerjaan kelas yang melibatkan siswa dalam memahami, memanipulasi, memproduksi atau berinteraksi dengan Bahasa target yang menitik beratkan pada eksplorasi grammatikal untuk menyampaikan makna (Nunan, 2004). Sedangkan tugas itu sendiri menuntut penyelesaian yang utuh yang dimulai dari pemahaman terhadap materi, kemampuan memecahkan masalah yang dituangkan dalam bentuk aplikasi terhadap terselesaikannya tugas yang diberikan. Maka, selain latihan yang diberikan untuk mendampingi materi, tugas yang diberikan dalam suatu mata kuliah harus dapat membuat mahasiswa mengkombinasikan keterampilan yang kompleks tersebut. Hal ini harus diberikan dengan cara yang tidak rumit dan sederhana untuk memudahkan guru/dosen/tutor menilai dengan baik tanpa menyita waktu yang banyak.

Metode pembelajaran ini secara umum dapat diaplikasikan dan dimanfaatkan oleh semua tutor dalam berbagai jurusan yang ditawarkan dalam Tutorial Online UT dan secara khusus penulis terapkan dalam jurusan Sastra Inggris Bidang Minat Penerjemahan FHISIP UT. Paparan berikut akan menjelaskan tentang konsep pembelajaran berbasis proyek atau tugas, penerapannya dalam kelas online, langkah-langkah menyusun materi dan diakhir akan dipaparkan rubrik dan model penilaian yang dapat digunakan.

\section{B. MODEL PEMBELAJARAN TASK-BASED LEARNING DALAM TUTORIAL ONLINE}

Pada dasarnya pembelajaran berbasis tugas atau proyek adalah model pembelajaran yang menuntut mahasiswa untuk belajar secara nyata. Model pembelajaran ini menuntut mahasiwa untuk praktek secara secara riil dengan mengaplikasikan teori kepada sebuah proyek yang dapat dikerjakan secara individu maupun berkelompok. Model pembelajaran task-based learning ini selaras dengan prinsip e-learning dimana siswa dapat melakukan proses pembelajaran secara mandiri. Prinsp-prinsip task-based learning yang mendukung tutorial online diantaranya adalah:

a. Memberikan kemudahan untuk disesuaikan dalam bahan ajar.

b. Memberikan penekanan komunikasi dalam Bahasa target.

c. Menggunakan materi ajar yang autentik.

d. Fokus pada proses belajar bukan hasil belajar yang disertai dengan pengawasan.

e. Mengubungkan pengalaman belajar dikelas dengan penggunaan Bahasa diluar kelas (Nunan dalam Wulandari, 2017).

Metode Task-Based Learning yang dikhususkan untuk pembelajaran bahasa menekankan pada negosiasi makna yang berproses dengan kegiatan penyelesaian tugas secara komunikatif dan memberikan siswa kesempatan untu mempraktekkan Bahasa dengan konteks makna, mengikutsertkan peserta dengan bahasa yang autentik, dan proses produksi bahasa secara 
kontekstual dimana bahasa bukanlah tujuan namun alat untuk mencapai target pembelajaran (Arslanyilmaz, 2012).

Universitas Terbuka menyediakan program studi Sastra Inggris bidang minat penerjemahan. Sama halnya dengan program studi lain, Sastra Inggris di UT juga menawarkan bantuan belajar elearning. Prodi Sastra Inggris di UT ini berkonsentrasi pada penerjemahana baik Inggris ke Indonesia maupun Indonesia ke Inggris. Untuk itu, kurikulum yang ditawarkan prodi ini hampir sebagian besar mata kuliah terjemahan, baik itu teori maupun praktek. Terdapat 10 mata kuliah Terjemahan dengan total 40 sks (http://www.fhisip.ut.ac.id/22-kategori/mahasiswa/sipas/17-kurikulum-sastra-inggris). Sehingga, praktek-praktek yang dipelajari oleh mahasiswa tidak jauh dengan apa yang akan dilakukan mereka kelak di dunia kerja, sehingga Model Task-Based Learning ini merupakan salah satu metode yang sangat membantu proses pembelajaran mahasiswa.

Nunan (2004) menggagas beberapa langkah-langkah yang dapat dilakukan untuk menyusun materi dengan menggunakan metode Task-Based Learning. Tahap-tahap penyusunan materi yang sesuai dengan karakteristik pembelajaran online diantaranya sebagai berikut:

1. Memilih tugas target/ tugas proyek yang riil (sesuaikan dengan karakteristik dan kemampuan siswa).

Tahapan yang pertama untuk memilih bentuk tugas proyek adalah mempertimbangkan kemampuan dan kompetensi mahasiswa, waktu yang dibutuhkan untuk menyelesaikan dan output atau hasil yang diharapkan untuk tercapai. Mengingat bantuan belajar e-learning yang disediakan oleh UT terbatas oleh waktu, tentunya tugas proyek yang diberikan harus memiliki durasi waktu penyelesaian tidak lebih dari tujuh hari. Hal ini dikarenakan, materi inisiasi yang diberikan dalam bantuan belajar berjumlah 8 (delapan) iniasiasi dan masing-masing memiliki waktu penyelesaian idealnya tidak lebih dari 1 minggu. Namun, mhasiswa masih diberikan kelonggaran untuk dapat mengerjakan hingga akhir masa tutorial atau sampai materi ditutup oleh PBB UT. Mahasiswa yang mengerjakan tidak sesuai dengan jangka waktu yang diberikan akan mendapatkan nilai tidak lebih baik dari mereka yang mengerjakan sesuai dengan jangka waktu yang sudah ditentukan.

Tugas yang dipilih harus sesuai disesuaikan dengan kompetensi dan kemampuan siswa. Maka, untuk mahasiswa tahun pertama tugas yang diberikan memiliki tingkat kesukaran yang lebih rendah dari mereka yang berada di tahun kedua. Selain itu, karena Task-Based Learning menekankan pada tugas riil, tugas proyek harus didesain agar semua mahasiswa peserta tutorial mampu mengerjakan dengan baik merskipun meraka berada di tempat yang jauh berbeda dengan latar belakang dan karakteristik yang berbeda-beda pula. Selain itu, pada tahap ini tutor harus menyatakan dengan jelas tujuan atau target yang harus dicapai diakhir pembelajaran. Tutor harus menyatakan dengan jelas seperti; di akhir inisiasi mahasiswa akan mampu untuk a, b, dan c. Yang dimaksud a, b, dan c disini merujuk pada kata kerja yang terukur dengan indikator dalam Rancangan Aktivitas Tutorial.

\section{Membentuk skema aktifitas tugas pedagogik}

Tugas pedagogik dibagi menjadi dua yaitu tugas latihan dan tugas aktivasi (Nunan, 2004). Tahap ini diberikan sebelum mahasiswa memulai mengerjakan tugas proyek yang sudah dipilih dalam tahapan proses sebelumnya. Pada tahap ini, dosen/tutor memberikan kerangka atau langkahlangkah yang bisa diikuti untuk mulai mengerjakan tugas proyek yang diberikan. Buatlah dengan tingkat kesukaran sesuai dengan kemampuan dan karakteristik mahasiswa. Sebagai contoh dalam Mata Kuliah Translation 1 pada tema Public Places kita dapat meminta menerjemahkan sign boards 
di tempat-tempat umum tersebut. Untuk tahapan awal sign board dapat berisi tidak lebih dari 10 kata seperti contoh berikut ini:

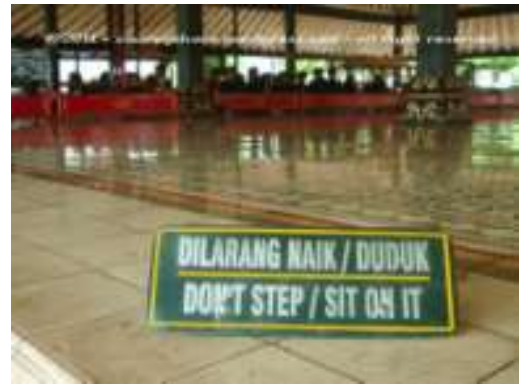

(https://sowanyahara.wordpress.com/2011/04/)

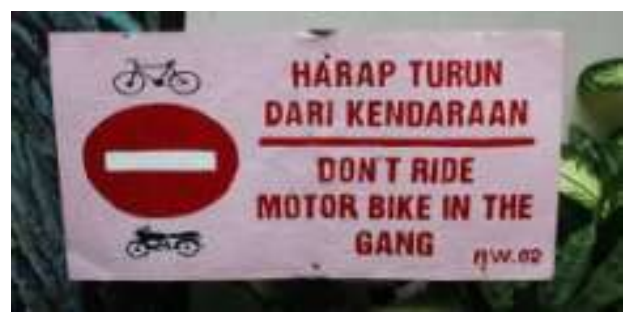

(https://englishcoo.com/)

Dalam gambar diatas, disajikan perintah yang lazim berada ditempat umum seperti yang ada digambar adalah di keraton (tempat wisata) dan di jalan raya. Papan peringatan (sign boards) disajikan dalam dua Bahasa yakni Bahasa Indonesia dan Bahasa Inggris. Kedua papan peringatan ditulis menggunakan Bahasa yang efektif singkat dan padat dalam bahasa sumber. Karena fokus mata kuliah adalah terjemahan maka mahasiswa harus menilai apakah terjemahan yang dihasilkan sesudah sesuai atau belum. Kemudian jika belum, mahasiswa harus merevisi redaksi penulisan terjemahan yang benar. Inilah yang disebut dengan skema tugas pedagogik dimana alurnya adalah sebagai berikut:
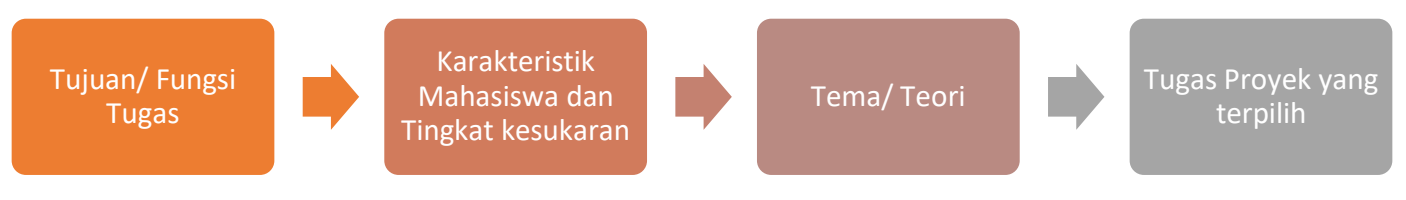

3. Melaksanakan tugas praktik terkontrol

Setelah menentukan tugas untuk mahasiswa, tentunya kita harus memberikan petunjuk bagaimana agar siswa dapat menyelesaikan tugas tersebut dan mencapai target pembelajaran yang telah diatur. Namun, karena jenis pembelajaran yang dibahas dalam tulisan ini adalah tutorial online, maka dosen tidak bisa mengontrol secara langsung. Untuk itu dosen perlu memberikan waktu kepada mahasiswa agar mereka bisa berlatih mengerjakan tugas secara mandiri. Setelah itu berilah kesempatan kepada mahasiswa untuk berdiskusi dan menyerahkan draft tugas kepada tutor untuk dikoreksi terlebih dahulu bagian mana yang sudah sesuai dengan petunjuk dan bagian mana yang belum sesuai. Hal ini untuk menghindari adanya kesalahan pada penyelesaian tugas akhir.

\section{Fokus pada bentuk}

Tugas proyek yang dipilih pada metode Task-Based Learning adalah tugas riil yang sesuai dengan konteks dan memiliki makna atau fungsi bahasa sebagai alat untuk berkomunikasi, bukan bahasa sebagai objek belajar. Untuk itu, pada tahapan ini proses Bahasa Inggris sebagai bahasa target harus digunakan sebagai alat untuk menyelesaikan tugas proyek dengan menggabungkan antara susunan kalimat (structure), tata bahasa (grammar), dan makna dalam konteks (pragmatics). 
Sebagai contoh mahasiswa dapat menggunakan foto dari keluarga, teman dekat, atau teman-teman di lingkungan tempat mereka berada untuk menyebutkan kata sifat dan mendeskripsikan tampilan fisik (physical appearance) yang ditampilkan dalam foto tersebut.

5. Memberikan peluang untuk latihan yang bebas melalui kegiatan komunikatif

Pada tahap ini mahasiswa dapat berkolaborasi dengan teman dalam kelas yang sama untuk menganalisis dan mengevaluasi (peer-review). Jika hal ini tidak memungkinkan, mahasiswa dapat mengunggah tugas yang sudah dikerjakan dan dalam Forum Diskusi teman-temannya yang lain dapat mengomentari atau mengoreksi jika terdapat kekeliruan dalam pengerjaan tugas. Proses ini membangun kemandirian mahasiswa untuk menilai sendiri (self-assessment) hasil belajar mereka melalui proses aktifitis komunikatif (communicative activity) dengan sesama peserta tutorial.

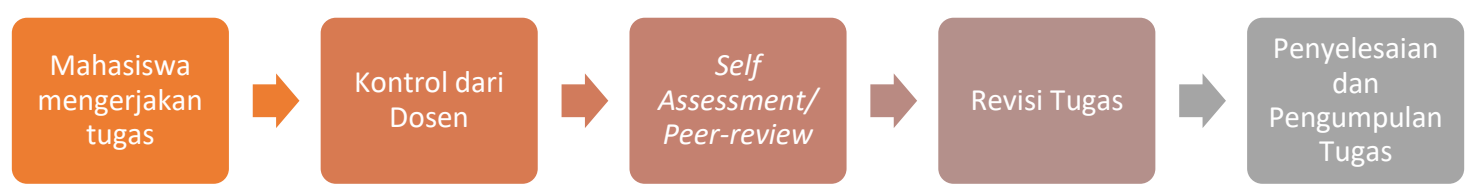

6. Refleksi dan evaluasi tugas yang mencerminkan target atau tugas riil

Jika mahasiswa sudah merevisi kembali tugas proyek yang mereka buat setelah adanya koreksi dari teman sejawat atau dosen, maka pada tahap ini adalah proses pemerikasaan akhir sebelum penyelesaian. Mahasiswa harus memeriksa apakah tugas yang diberikan sudah sesuai dengan tujuan dan target pembelajaran yang disampaikan oleh tutor pada tahapan yang paling awal.

7. Fokus pada proses pembelajaran

Tahapan ini bukanlah tahapan paling akhir dari metode Task-Based Learning yang diterapkan pada tutorial online melainkan proses harus dilakukan dari tahap awal penyusunan target hingga proses akhir yaitu refleksi dan evaluasi. Pada prinsipnya bahasa bukanlah target pembelajaran melainkan sarana yang digunakan pada proses pembelajaran secara komunikatif, pragmatis, dan merupakan perwujudan dari dunia nyata. Implementasi penggunaan bahasa dalam dunia nyata merupakan fokus dari metode ini, sehingga dosen atau tutor perlu memiliki kecakapan dan keterampilan yang baik dalam menyusun materi pembelajaran dengan metode ini.

Dosen atau tutor perlu memahami dengan baik bahwa tutorial online tidak sekedar media bantuan belajar mahasiswa saja melainkan juga merupakan sarana agar mahasiswa dapat menggali ilmu pengetahuan dan menerapkannya secara nyata sesuai dengan konteks. Karena jika tutorial online hanya sebatas penerapan teori yang dilengkapi dengan soal dan latihan tertulis saja maka hal ini tidak lebih dari sekedar pemahaman secara tekstual saja. Mahasiswa UT yang tersebar di beberapa tempat tidak hanya mahasiswa yang berharap pada sertifikat kelulusan dan titel saja, melainkan harus ada ilmu pengetahuan yang terserap yang mampu digunakan dan bermanfaat bagi dunia mereka. Task-Based Learning akan menjadi model pembelajaran yang efektif apabila digunakan secara tepat dengan memahami dan mengetahui prinsip-prinsip. Sekali lagi, metode ini akan mendukung proses belajar secara mandiri yang sudah menjadi prinsip dalam tutorial online itu sendiri. 


\section{SIMPULAN}

Bantuan belajar tutorial online yang dapat dimanfaatkan oleh Mahasiswa UT seharusnya menjadi media belajar bagi mahasiswa untuk membangun proses belajar mandiri, kreatif, dan inovatif. Mahasiswa diharapkan mampu berfikir secara kritis dan kreatif dengan memperkaya teori yang dapat diperoleh dari sumber lain selain BMP. Selain itu, materi yang diberikan dalam tutorial online dan arahan dari tutor diharapkan juga mampu menyempurnakan pengetahuan yang ingin dicapai dalam proses belajar mandiri mereka. Proses belajar ini tidak akan melekat sempurna apabila tidak disertai dengan praktek dan aplikasi belajar secara riil yang dilakukan oleh Mahasiswa. Untuk itu, pendampingan materi dalam bentuk tes, tugas, maupun kerja proyek perlu diberikan kepada mahasiswa tanpa membebebani waktu belajar dan kegiatan mahasiswa. Bentuk tugas ataupun proyek dapat dikerjakan secara individu, teman berpasangan, maupun kelompok. Sehingga, mahasiswa akan mengerti betul konsep teori yang dikolaborasikan dengan aplikasi proyek untuk mendukung karir dalam dunia nyata mereka yang sesungguhnya,

\section{REFERENSI}

Arslanyilmaz, A. (2012). An Online Task-Based Language Learning Environment: Is it Better for Advanced-or Intermediate Level Second Language Learners? The Turkish Online Journal of Educational Technology, Vol 11 No. 1.

Nunan, D. (2004). Task-Based Language Teaching. Cambridge: Cambridge University Press. Sugilar. (2014). Pemanfaatan UT Online oleh Mahasiswa Universitas Terbuka. Jurnal Pendidikan Terbuka dan Jarak Jauh, Vol.15, No. 1 Hal 43-53.

Wulandari, D, dkk. (2017). Penerapan Task-Based Learning dalam Pelatihan Bahasa Inggris terkait Kriminalitas bagi Personel Polrestabes Semarang. Jurnal HARMONI, Vol 1 No. 1 Hal 89-96.

\section{Referensi gambar:}

https://sowanyahara.wordpress.com/2011/04/.

https://englishcoo.com/. 